\title{
Seasonal variation and flux of dissolved nutrients in the Danshuei Estuary, Taiwan: A hypoxic subtropical mountain river
}

\author{
Liang-Saw Wen $^{\mathrm{a}, *}$, Kuo-Tung Jiann ${ }^{\mathrm{b}}$, Kon-Kee Liu ${ }^{\mathrm{c}}$ \\ a Institute of Oceanography, National Taiwan University, Taipei, Taiwan, ROC \\ ${ }^{\mathrm{b}}$ Institute of Marine Geology and Chemistry, National Sun Yat-Sen University, Taiwan, ROC \\ ${ }^{\mathrm{c}}$ Institute of Hydrological Sciences, National Central University, Taiwan, ROC
}

\section{A R T I C L E I N F O}

\section{Article history:}

Received 4 December 2006

Accepted 19 February 2008

Available online 29 February 2008

\section{Keywords:}

nutrients

nitrogen

phosphorus

silicon

rivers

estuaries

Taiwan

Asia

subtropical

\begin{abstract}
A B S T R A C T
Comprehensive bimonthly field surveys were carried out from September 2000 to June 2002 to study the seasonal dynamics and the inter-annual variability of dissolved inorganic nitrogen (DIN; nitrate, nitrite and ammonium) and dissolved inorganic phosphorus (DIP) in a subtropical mountain river system, the Danshuei tributary, the largest urbanized estuarine system in Taiwan. The headwaters were found to be well aerated, saturated with oxygen, with low ambient DIN $(<9 \mu \mathrm{M})$ and DIP $(<0.2 \mu \mathrm{M})$ concentration. As the river flows through the city of Taipei, the river becomes hypoxic because re-aeration rates cannot keep up with elevated oxygen consumption, and the concentrations of DIP $(7.53 \mu \mathrm{M})$ and DIN $(\sim 390 \mu \mathrm{M})$ increase drastically. Conservative mixing was mostly observed for silicate while DIP and DIN mostly showed non-conservative removal characteristics. Silicate originates from weathering and erosion of bedrocks in the watershed, whereas nitrogen- and phosphorus-bearing nutrients come mainly from urban discharges. Ammonium is the predominant dissolved nitrogenous species, ranging from 10 to $1000 \mu \mathrm{M}$. The nutrient chemistry is complex and dynamic due to anthropogenic perturbations and reactions in the tidally mixed zone of strong redox gradients. On average, the annual loading rates of dissolved phosphate and dissolved inorganic nitrogen from the Danshuei River to the ocean are 0.1 and $3.2 \mathrm{Gmol} /$ year, respectively, which represent $0.1 \%$ and $0.2 \%$ of the world's total river discharge of dissolved inorganic nitrogen and phosphate.
\end{abstract}

(c) 2008 Elsevier Ltd. All rights reserved.

\section{Introduction}

Land-ocean interactions in the coastal zone are currently the focus of regional and global research, to quantify fluxes of materials from the land to the coastal region and determine the changes and effects of human usage on the coastal environment (Rabalais, 2002; Dumont et al., 2005; Boyer et al., 2006). Studies have indicated that $1.9 \%$ of estimated global sediment discharge is derived from Taiwan, which covers only $0.024 \%$ of the Earth's sub-aerial surface (Li, 1976; Griffiths and Glasby, 1985; Milliman et al., 1999; Dadson et al., 2003). Once known as "Isla Formosa" (Beautiful Island), Taiwan's progress towards economic growth over the last half century has brought rapid industrial development and significant environmental degradation. Taiwan's environmental problems are also caused by population density; nearly 23 million people reside on a surface area less than $36,000 \mathrm{~km}^{2}$, among the most

\footnotetext{
* Corresponding author.

E-mail address: lswen@ntu.edu.tw (L.-S. Wen).
}

densely populated regions on earth. Moreover, most of the population is packed into the $2300 \mathrm{~km}^{2}$ of alluvial plain along the west coast of the island. This area is also home to the major agriculture and horticulture industries, as well as more than 8 million manufacturing facilities (EPA, 2006). Changing land use practices, increased surface water runoff and wastewater disposal have resulted in major changes in the receiving waters.

The global transport of $\mathrm{N}$ and $\mathrm{P}$ in rivers has increased greatly as a result of human activities (Rabalais, 2002; Dumont et al., 2005; Boyer et al., 2006). After Meybeck (1982), Smith et al. (2003) estimated that the total river-load of dissolved $\mathrm{N}$ has increased 6 times and that of $P$ has increased 9 times over pre-industrial levels. These increases are not evenly distributed around the world; they are strongly correlated with the human population in the drainage ba$\sin$ (Carpenter et al., 1998; Galloway et al., 2004; Green et al., 2004; Dumont et al., 2005). There are 118 rivers and streams in Taiwan, and 24 of these surface waters provide $85 \%$ of the water usage. $\mathrm{Nu}$ trient "overloads" are most pronounced in Taiwan, where human and animal waste products, in addition to those from industry and agriculture, are mostly directly discharged into rivers and transported to the coastal ocean, causing numerous pollution 
problems, especially over the last 40 years (Lao and Young, 1995; WRA, 2001, 2002). Urban communities are also the major culprits, primarily because of inadequate sanitary sewer systems. Only $10 \%$ of the population is served with sanitary sewers. Even in the capital city of Taipei, the sewer system was connected to about $59 \%$ of households as of mid-2002. There were no sanitary sewer systems serving its suburban areas, which drain their wastewaters into the Danshuei River, the largest tributary estuarine system in the country (WRA, 2001, 2002; EPA, 2006). Estuarine and coastal ecosystems in Taiwan, like those in other fast developing South Asian countries, are experiencing accelerated declines in water quality. This can have a profound impact on the global oceanic nutrient balance.

Here we report the first extensive systematic study of the largest estuarine system in Taiwan. In particular, we present and discuss: (1) the environmental characteristics of the subtropical mountainous river with three orders of magnitude variation in discharge rate; (2) inter-annual variability of the nutrient concentrations in river and estuarine waters; and (3) the implications for the contribution to the global biogeochemical cycle of nutrients in the coastal zone.

\section{Materials and methods}

\subsection{Study area}

The Danshuei River watershed (also know as the Tamsui River) encompasses $2726 \mathrm{~km}^{2}$, with a maximum length of about $70 \mathrm{~km}$ from the headwaters to the river mouth; it drains mountainous areas with maximum elevation of $3500 \mathrm{~m}$ (WRA, 2002). The river is shallow (1-15 m), with an average annual flow rate of $6600 \times 10^{6} \mathrm{~m}^{3}$, and receives freshwater inputs mainly from the Hsin-Dien Stream ( 37\%), Dai-Han Stream ( 31\%) and Keelung River ( $\sim 27 \%)$; together they form the largest estuarine system in Taiwan (Fig. 1) (WRA, 2002). The drainage basin includes several regions along the main tributaries where large amounts of nutrients, resulting from industrial and agricultural activities, enter the river. The main entry point is the metropolitan area of Taipei, the capital city of Taiwan, with a total population of 6 million. The upper reaches of the estuarine system, upriver from Guandoo, are within the Taipei basin. Most of the original mangrove swamps have long disappeared, claimed for urban development during the past 50 years; only a few patches near the river mouth remain. The regional

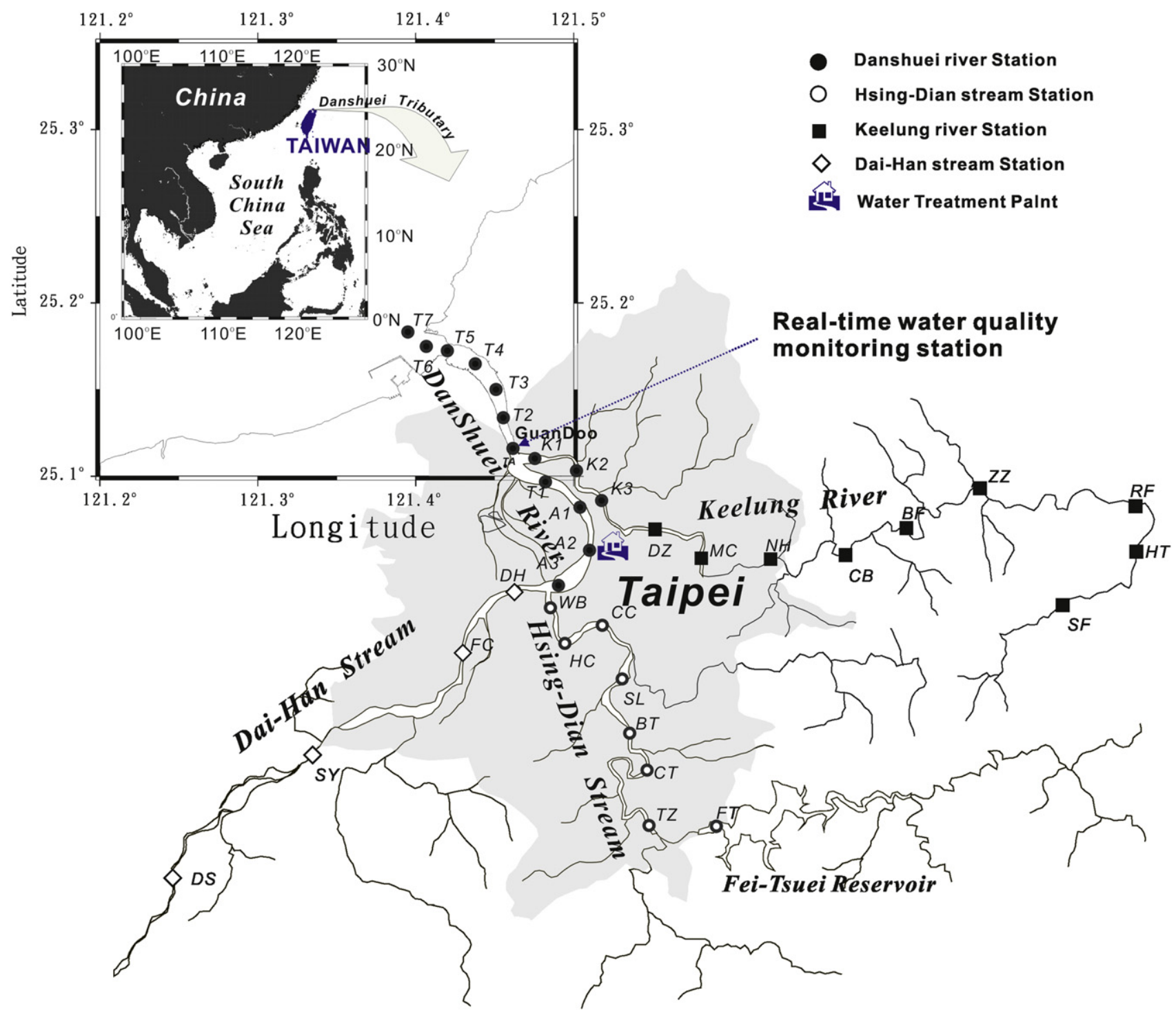

Fig. 1. Map of Danshuei River tributaries showing sampling locations and real-time water quality monitoring station. The city of Taipei is depicted as the shaded area. 
climate is subtropical with the temperature varying between 10 and $35^{\circ} \mathrm{C}$ and annual precipitation ranging between 1500 and $2500 \mathrm{~mm}$; the dry season ranges from November to April and the wet season ranges from May to October.

The morphology of the Danshuei Estuary displays different features in each segment, molded by natural forces as well as anthropogenic activities exerted upon the paleo-riverbed built ages ago (Song et al., 2002). In the lower reaches immediately downstream of Guandoo, the riverbed exhibits a deep-cut cross-section, with channel depths of $12-15 \mathrm{~m}$ and a topographical high $(<5 \mathrm{~m})$ in the middle of the riverbed. Further downstream, towards the river mouth, the average depth is $3 \mathrm{~m}$ in the axial region. The river channel broadens with progressively shallower depths; deposits of sediments divide the river channel, which is flanked by broad, flat areas of salt marsh and mangrove forest. The lower reaches of the estuary and the adjacent salt marshes are subject to daily tidal inundation. Mountains surround the estuary; therefore, no significant wind-induced currents occur within the estuary, except during storm surges. The major forcing of the flows are astronomical tides and river discharges. The instantaneous water discharge rate varies greatly over time as a response to episodic events, such as typhoons, which often bring torrential rains and increase river flow (Fig. 2). The principal local tidal constituents lean toward semi-diurnal tides, with form ratios of $0.2(<0.25)$, and a mean tidal range of $2.1 \mathrm{~m}$ and a spring tidal range of $3.5 \mathrm{~m}$, leading to a tidal excursion distance of 10-20 km upriver, depending on the weather conditions (WRA, 2001, 2002). Meteorological tides, induced by typhoons or weather fronts, can cause water levels to rise about $2 \mathrm{~m}$ above the astronomical levels during critical conditions, and may be one of the most important factors in estuarine flushing. The baroclinic flow forced by seawater intrusion is also an important transport mechanism in the Danshuei estuarine system (Liu et al., 2002).

\subsection{Sampling program}

Comprehensive field sampling expeditions, totaling 14 surveys, were carried out from September 2000 to June 2002 within the estuary, stations as shown in Fig. 1. The surface water samples were collected during both tidal conditions (flood and ebb) over the entire salinity range. In general, at least two boats $(\sim 10 \mathrm{ft}$,) were used for each survey to optimize temporal and spatial coverage. Vertical water column profiles were measured with a multi-sensor CTD unit (SeaBird 911, equipped with dissolved oxygen, and fluorescence sensors). On all occasions, the sampling stations were evenly spread and kept in the center of the channel, extending from the estuarine mouth to approximately $25 \mathrm{~km}$ upstream where the DaiHan stream flows into the Danshuei River channel (Station A3 in Fig. 1). In October 2001, the field survey was extended from the middle reaches to the headwaters of the Hsin-Dien, Dai-Han and Keelung Rivers (Fig. 1). Both filtered and unfiltered samples were collected using a peristaltic pump system equipped with Teflon tubing inlets and outlets. For sample collection, the tubing was
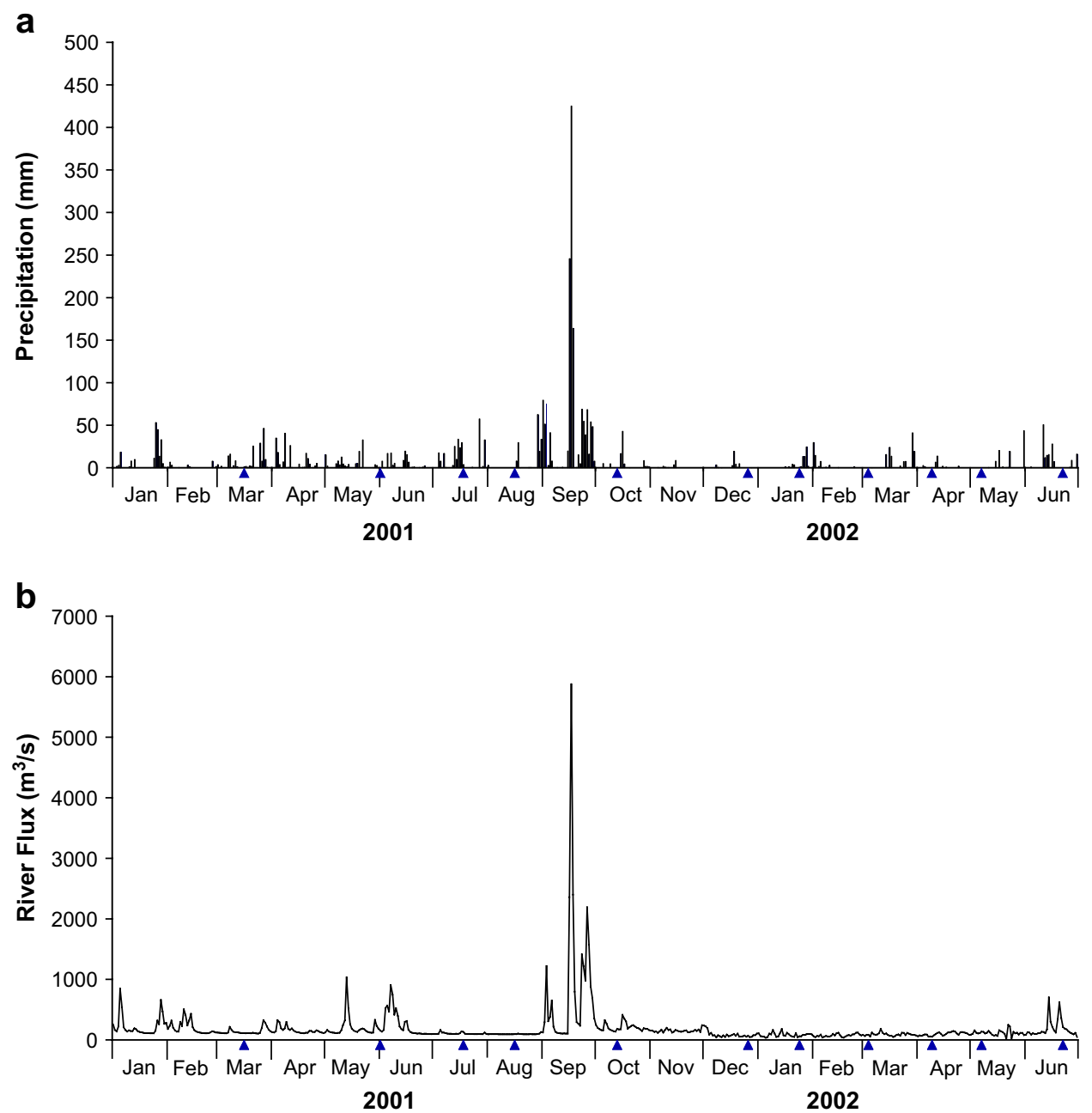

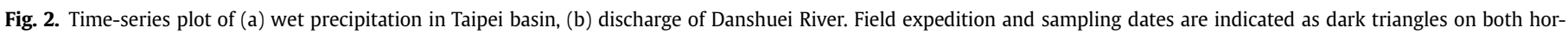
izontal axes. 
Table 1

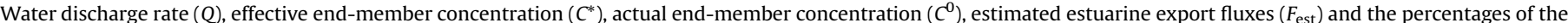

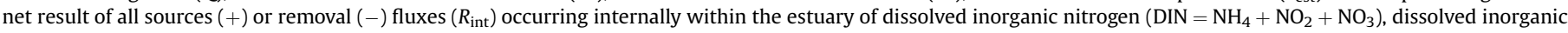
phosphate (DIP) and dissolved silicate (DSi) in the water column of Danshuei River during different field surveys

\begin{tabular}{|c|c|c|c|c|c|c|c|c|c|c|c|c|c|}
\hline \multirow{2}{*}{$\begin{array}{l}\text { Survey date } \\
\text { (Y/M/D) }\end{array}$} & \multirow{2}{*}{$\begin{array}{l}\text { Discharge } \\
Q\left(\mathrm{~m}^{3} / \mathrm{s}\right)\end{array}$} & \multicolumn{4}{|l|}{ DIN } & \multicolumn{4}{|l|}{ DIP } & \multicolumn{4}{|l|}{ DSi } \\
\hline & & $\begin{array}{l}C^{*} \\
(\mu \mathrm{M})\end{array}$ & $\begin{array}{l}C^{0} \\
(\mu \mathrm{M})\end{array}$ & $\begin{array}{l}F_{\text {est }} \\
\left(10^{6} \mathrm{~mol} / \text { day }\right)\end{array}$ & $\begin{array}{l}R_{\text {int }} \\
(\%)\end{array}$ & $\begin{array}{l}C^{*} \\
(\mu \mathrm{M})\end{array}$ & $\begin{array}{l}C^{0} \\
(\mu \mathrm{M})\end{array}$ & $\begin{array}{l}F_{\text {est }} \\
\left(10^{6} \mathrm{~mol} / \text { day }\right)\end{array}$ & $\begin{array}{l}R_{\text {int }} \\
(\%)\end{array}$ & $\begin{array}{l}C^{*} \\
(\mu \mathrm{M})\end{array}$ & $\begin{array}{l}C^{0} \\
(\mu \mathrm{M})\end{array}$ & $\begin{array}{l}F_{\text {est }} \\
\left(10^{6} \mathrm{~mol} / \text { day }\right)\end{array}$ & $\begin{array}{l}R_{\text {int }} \\
(\%)\end{array}$ \\
\hline $2001 / 03 / 16$ & 110 & 532 & 485 & 5.06 & +10 & 27.4 & 20.3 & 0.261 & +35 & 225 & 172 & 2.15 & +31 \\
\hline $2001 / 06 / 01$ & 155 & 294 & 268 & 3.94 & +9 & 8.2 & 12.4 & 0.110 & -34 & 189 & 206 & 2.53 & -8 \\
\hline $2001 / 06 / 19$ & 105 & 229 & 259 & 2.07 & -12 & 10.9 & 18.0 & 0.099 & -39 & 191 & 227 & 1.73 & -16 \\
\hline $2001 / 07 / 18$ & 132 & 256 & 205 & 2.92 & +25 & 5.8 & 4.61 & 0.067 & +26 & 160 & 125 & 1.82 & +28 \\
\hline $2001 / 08 / 16$ & 95 & 574 & 548 & 4.71 & +5 & 14.0 & 20.1 & 0.115 & -30 & 41 & 278 & 0.34 & -85 \\
\hline $2001 / 10 / 13$ & 183 & 253 & 257 & 3.97 & -2 & 4.2 & 5.56 & 0.065 & -26 & 183 & 138 & 2.88 & +33 \\
\hline $2001 / 12 / 26$ & 69 & 363 & 484 & 2.15 & -25 & 6.9 & 10.4 & 0.041 & -33 & 249 & 264 & 1.47 & -6 \\
\hline $2002 / 01 / 24$ & 52 & 697 & 660 & 3.12 & +6 & 19.9 & 23.1 & 0.089 & -14 & 230 & 222 & 1.03 & +4 \\
\hline $2002 / 03 / 04$ & 82 & 736 & 670 & 5.24 & +5 & 18.2 & 29.8 & 0.130 & -39 & 232 & 233 & 1.65 & -0.3 \\
\hline $2002 / 04 / 09$ & 91 & 605 & 530 & 4.78 & +14 & 19.2 & 28.5 & 0.152 & -33 & 231 & 229 & 1.82 & +1 \\
\hline $2002 / 05 / 07$ & 137 & 793 & 693 & 9.42 & +14 & 25.4 & 29.3 & 0.301 & -14 & 232 & 261 & 2.75 & -11 \\
\hline $2002 / 06 / 22$ & 214 & 451 & 490 & 8.33 & -8 & 13.8 & 17.9 & 0.255 & -23 & 166 & 221 & 3.06 & -25 \\
\hline
\end{tabular}

attached to a non-metallic pole and the tubing inlet was oriented into the current at a depth of about $0.25 \mathrm{~m}$ to obtain water untouched by the exterior of the sampling apparatus. Prior to sample collection, the sampling system was flushed for 5-10 min at a flow rate of approximately $300 \mathrm{ml} / \mathrm{min}$ to remove any possible residues in the tubing from the cleaning process. Unfiltered samples were drawn directly into acid-cleaned sample bottles. Filtered samples were obtained by attaching an acid-cleaned polyethylene membrane cartridge $(0.45 \mu \mathrm{m}$; MSI Micron Separations, Westborough, MA, USA) to the pump outlet and dispensing the water directly into acid-cleaned sample bottles. Unfiltered waters for chlorophylla measurement were filtered aboard ship through Whatman GF/F filters and the filters were kept in an LN tank for further processing in the laboratory. Clean techniques were used during all stages of sample collection, transport, handling, processing, and analysis (Wen et al., 2002, 1999). In the September 2002 survey, in addition to surface water, mid-depth and near bottom $(\sim 30 \mathrm{~cm}$ above sediment) depth water samples were also collected by an acid-cleaned Go-Flo bottle (General Oceanics) attached on a PE line. To address the short-term variations, real-time water-quality monitoring began at the Guandoo station (TA) in May 2002 and continued through October 2003 using an in situ multi sensor unit (Hydrolab DataSonde 4a) for selected physical properties; specific conductance, $\mathrm{pH}$, water temperature, turbidity, fluorescence, and dissolved
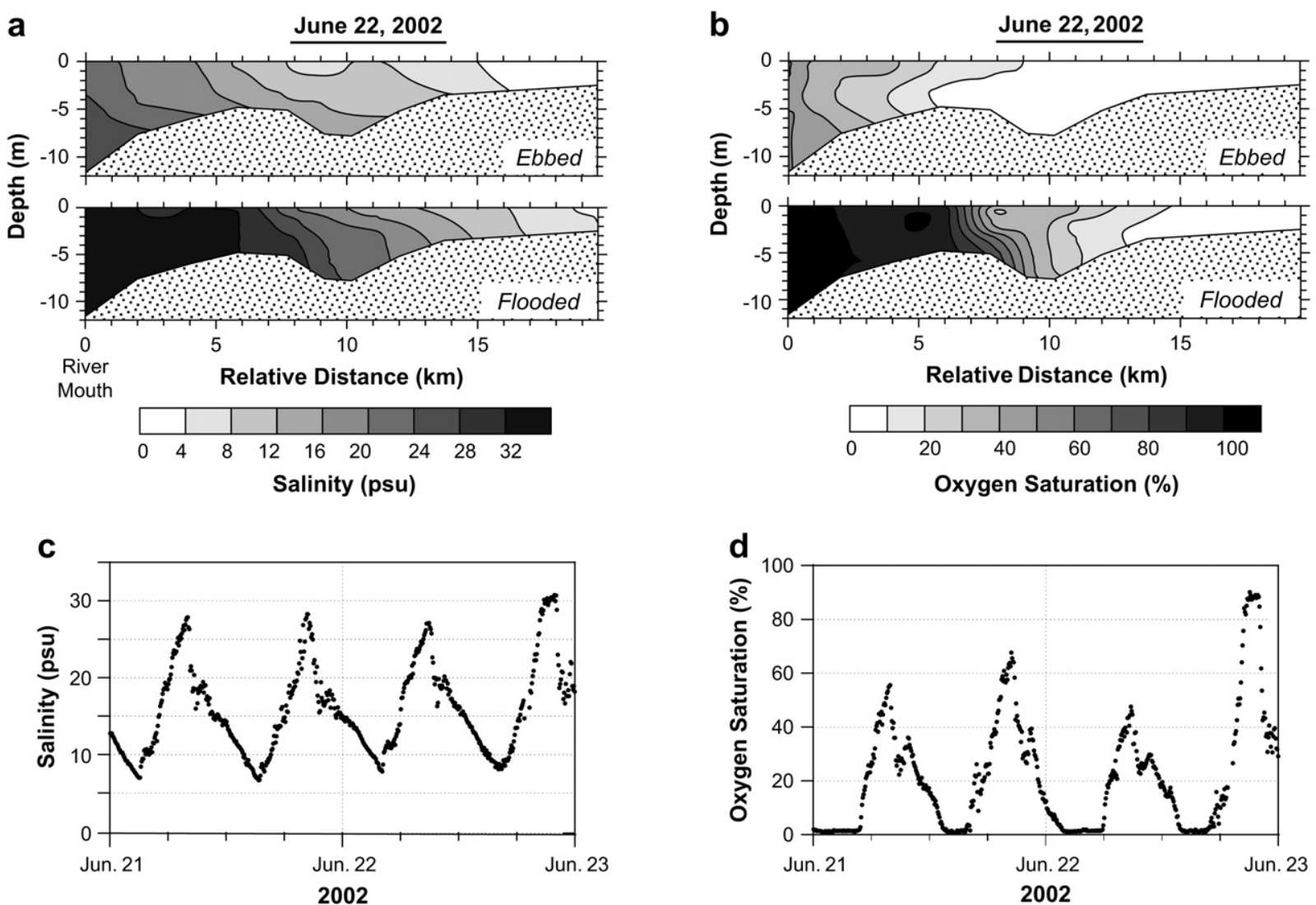

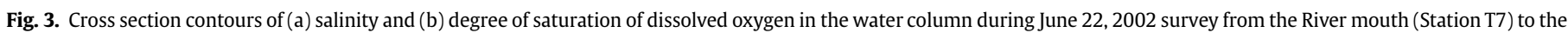

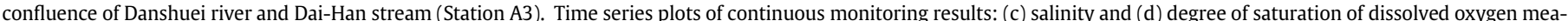

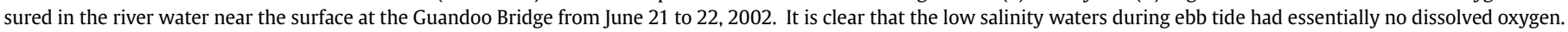


oxygen. The station instruments were serviced and calibrated every other week. Real-time data typically were recorded at 5-min intervals, stored onsite, and then transmitted to NTU offices every 1224 h. Prior to each use, the CTD units (SeaBird 911 and Hydrolab Datasonde 4a, including all attached sensors) were thoroughly calibrated according to the manufacturer's suggestions.

\subsection{Analysis}

The analyses performed on the filtered water samples for nutrients were conducted in the shore-based laboratory immediately after collection as follows: nitrite-nitrogen and nitrate-nitrogen were analyzed by the modified standard pink azo dye method adapted for a flow injection analyzer (Grasshoff, 1999); the salt/ionic effect on Cd column reduction efficiency and subsequent nitrate measurements were monitored and corrected (Ghassemzadeh et al., 1997; Chung et al., 2001); ammonium-nitrogen by an improved indophenol blue method (Pai et al., 2001); phosphate and silicate by the modified standard molybdenum blue method with a flow injection analyzer (Grasshoff, 1999); dissolved oxygen by a colorimetric method (Pai et al., 1993). The filters for chlorophyll- $a$ measurements were extracted in $5 \mathrm{ml}$ of 90\% HPLC-grade acetone, ultra-sonicated for $30 \mathrm{~s}$ and centrifuged to remove cellular debris. Pigment analysis was carried out by a modification reverse-phase HPLC method described by Mantoura and Llewellyn (1983). Station location and analytical results of all parameters are listed in the Supplementary Appendix.

\subsection{Estuarine flux calculations}

The estuarine mixing behavior of a constituent is conventionally interpreted by plotting the concentration of that constituent against salinity; the mathematical relationships for the mixing curves were derived (Boyle et al., 1974; Liss, 1976; Officer and Lynch, 1981). A conservative constituent will plot linearly versus salinity in a one-dimensional, two end-member, steady state system, while curvilinear correlations signify non-conservative behavior resulting in net addition or removal. Hence, for a non-conservative constituent, extrapolation of concentrations at high salinity to zero salinity yields an "effective" river concentration $\left(C^{*}\right)$ that would indicate the reactivity of a constituent within the estuary, and can be used to calculate the total flux of the constituent to the ocean. Specifically, when $C^{*}=C^{0}$ (the actual river concentration), the constituent is behaving conservatively; when $C^{*}<C^{0}$ the constituent is being removed from the estuary; and when $C^{*}>C^{0}$ the constituent is being input into the estuary. The fluxes (export loadings) to the ocean are estimated by multiplying the effective river concentration $\left(C^{*}\right)$ by the total river water flux $(Q)$. The flux of a constituent entering the estuary from the river is $F_{\text {riv }}=Q C^{0}$, the flux out is $F_{\text {sea }}=Q C^{*}$, and the net internal input or removal flux, either by a physical- a

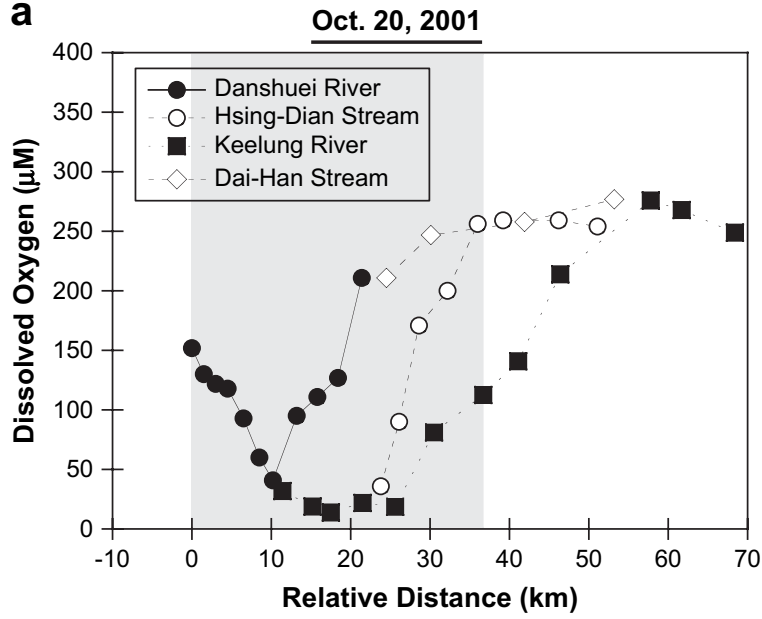

C

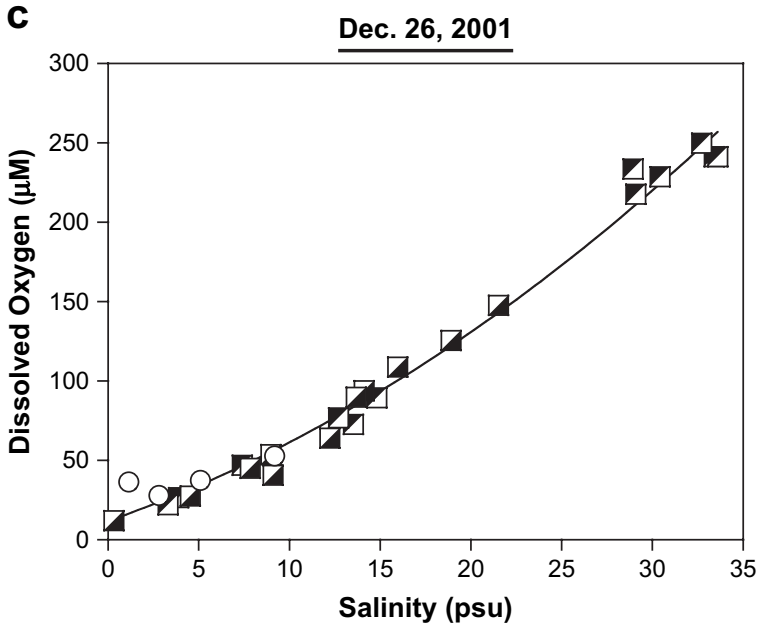

b

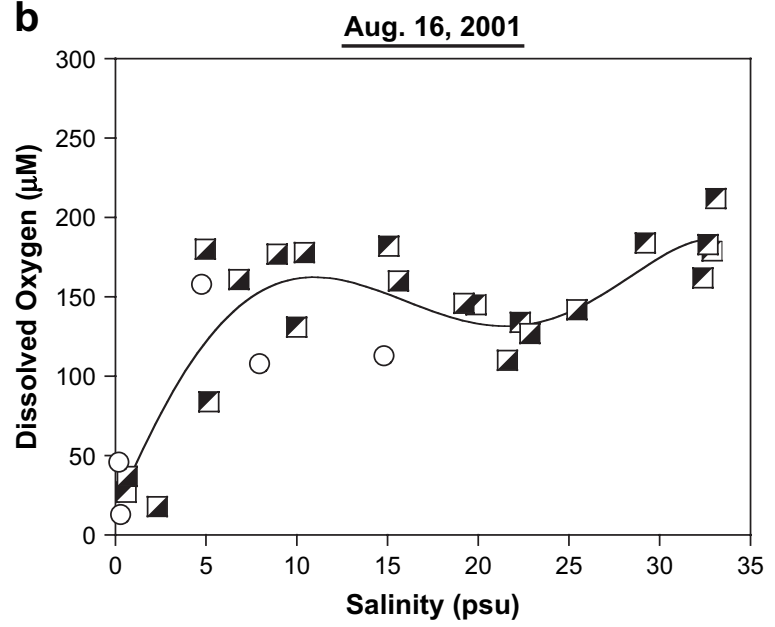

d
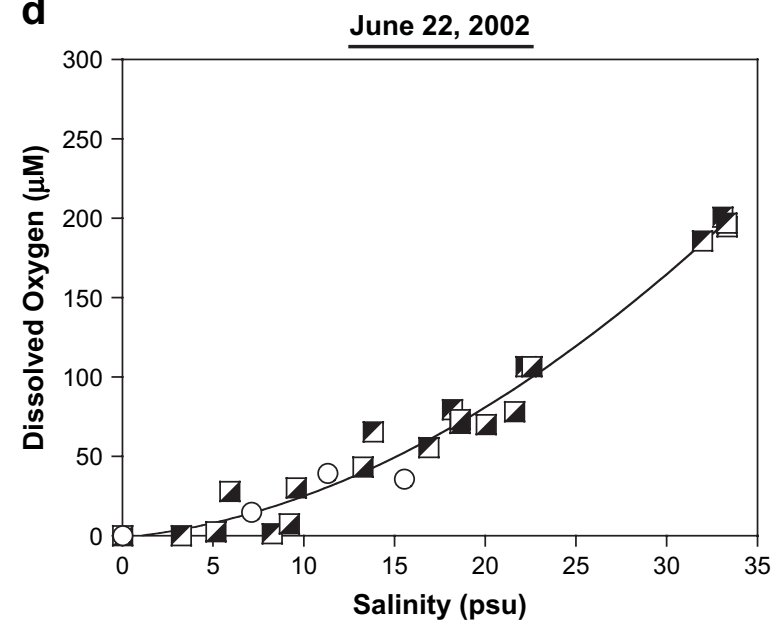

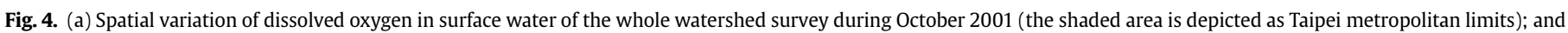

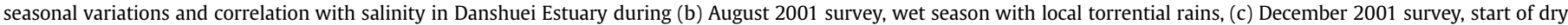
season, (d) June 2002 survey, end of dry season that year ( $\boldsymbol{\square}$, waters collected during flood tide; $\boldsymbol{\square}$ waters collected during ebb tide; , waters collected at Keelung River). 
chemical process (change of redox potential or aggregation) or biological activity is not specified, is given by the difference: $F_{\text {int }}=Q\left(C^{*}-C^{0}\right)$. In this study, to reduce the end-member variations, simplified into a single box model and improve the estimation of the effective concentration $\left(C^{*}\right)$, we used only those results for water collected from the lower part of the estuary, at the convergent point of the Keelung and Danshuei Rivers to the estuary mouth, and the river/tidal flows were continuously monitored and measured. The model simulation mixing line and effective concentration are shown in Figs. 6-8. Since our river data were collected at bi-monthly intervals, we could not resolve the periodicity of any shorter-term source variations that may be superimposed on the yearly cycle. And the "actual river concentration" $C^{0}$ was derived by the mixing variable using river endmember concentration $\left(C^{\mathrm{K}}\right.$ and $\left.C^{\mathrm{D}}\right)$ and river water flux $\left(Q^{\mathrm{K}}\right.$ and $\left.Q^{D}\right)$ from the Keelung and Danshuei Rivers in each case $\left[C^{0}=C^{\mathrm{K}}\left(R^{\mathrm{K}} / R\right)+C^{\mathrm{D}}\left(R^{\mathrm{D}} / R\right)\right]$. A summary of the modeling results for nutrients in different sampling periods is given in Table 1.

\section{Results}

\subsection{Salinity characteristic and distribution of the hypoxic zone}

On May 222002 survey results indicated (as also found at other times) a seawater front traveling upstream (during a flood tide), nearly reaching where the Dai-Han stream converges into the main channel of the Danshuei River, which can be identified on the basis of its salinity characteristics (Fig. 3a). Clear and oxygen saturated seawater mixes twice a day with murky anoxic river waters, as the seawater front travels upstream (during flood tides), whereby a layer of fresh but low oxygen water ends up sitting on top of the salt water (Fig. 3c). Recorded by the real-time water quality monitoring unit situated near Guandoo at the same time, the incursion of the saltwater front or the down flow of hypoxic fresh water has a 6-h time interval (Fig. 3b,d).

To further address the de-oxygenation conditions in the Danshuei tributaries, the field survey was extended to upstream of the Hsin-Dian stream, the Dai-Han stream and the Keelung River during October 13-17, 2001 (stations shown in Fig. 1). Results indicate that the headwaters of all three tributary streams were well aerated, and the dissolved oxygen concentrations were high and saturated, as the river flowed through the city of Taipei (shaded area in Fig. 4a), the oxygen concentration drops produced a typical sag curve of dissolved oxygen, as shown in Fig. 4a. While the Dai-Han stream had the highest oxygen concentrations, which counteracted the effects of the deoxygenated waters from the Hsin-Dian stream, the oxygen concentration in surface waters of the Keelung River dropped rapidly even before flowing into Taipei. The distributions of dissolved oxygen as a function of salinity in surface waters further detailed the hypoxic nature and strong tidal mixing behavior in the water column of the estuarine region, producing distinct distribution patterns in different seasons (Fig. 4). With torrential rains and large freshwater inputs, the oxygen concentration remained high (Fig. 4b), while with very low freshwater a

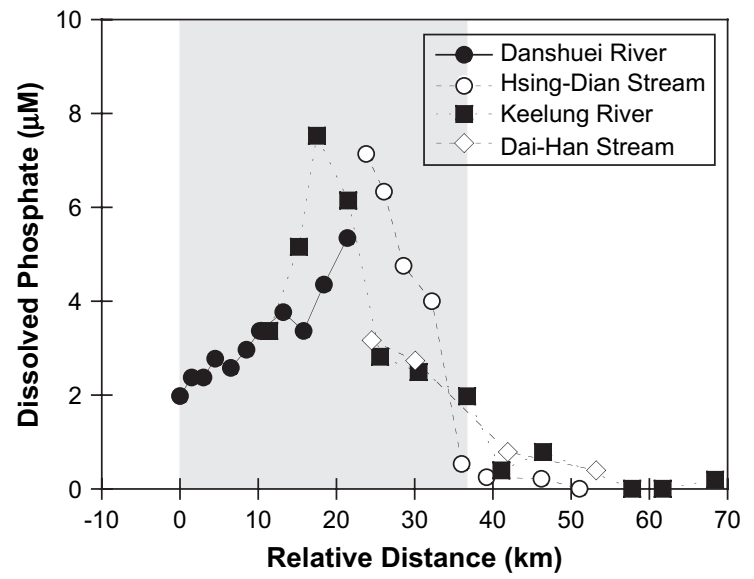

C

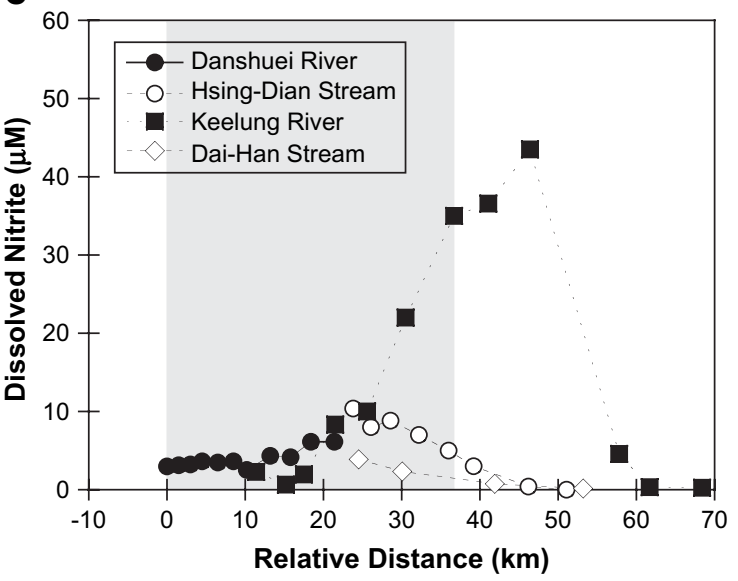

b

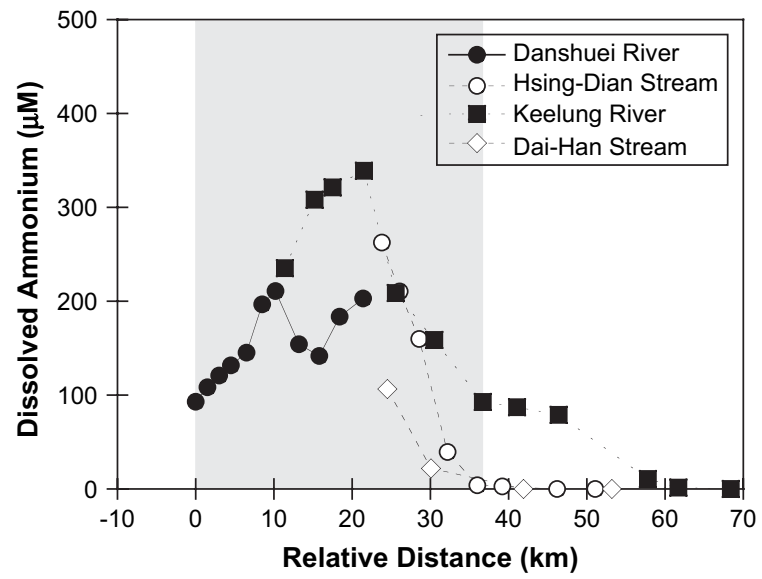

d

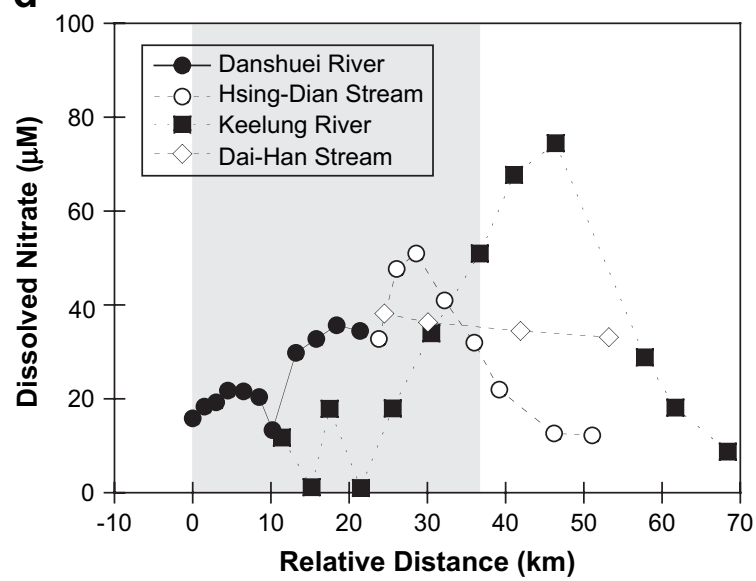

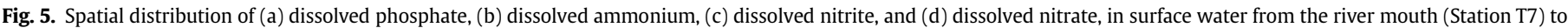
headwaters in whole watershed survey during October 2001. The shaded area is depicted as Taipei metropolitan limits. 
input, the water column remained consistently hypoxic (Fig. 4c,d). Nevertheless, the surface waters at the river mouth were mostly oxygen saturated; no hypoxic situations were found during any of the surveys.

\subsection{Spatial variations of dissolved inorganic phosphate and nitrogen}

During the whole Danshuei watershed survey conducted in October 2001, results showed that the concentration of dissolved phosphate in surface water ranged between 0.01 and $7.5 \mu \mathrm{M}$ in the whole Danshuei watershed, low ambient concentrations were observed for the headwaters of Hsin-Dian stream $(\sim 0.01 \mu \mathrm{M})$ and Keelung River $(\sim 0.2 \mu \mathrm{M})$, with slightly higher values shown in the Dai-Han stream $(\sim 0.4 \mu \mathrm{M})$ (Fig. 5a). As the rivers flowed through the metropolitan area of Taipei (shaded area in Fig. 5), concentrations of DIP increase drastically. On the way to the sea, the concentration of reactive phosphate continually decreases due to dilution with seawater. For dissolved inorganic nitrogen, ranging between 5.5 and $390 \mu \mathrm{M}$, similar distribution trends were also observed for all nitrogen species (Fig. 5b-d). No nitrite and ammonium were measurable in the headwaters, but there was a considerable quantity of nitrate, especially in the Dai-Han stream, with headwater concentrations reaching $33 \mu \mathrm{M}$. Concentrations of ammonium, the predominant dissolved nitrogenous species found within the river water of the city of Taipei, were extremely high $(\sim 350 \mu \mathrm{M})$, almost reaching toxic levels for aquatic organisms.
Much higher concentrations of nitrite and nitrate were observed in Keelung River waters, and maximum concentrations for both analytes were found just before the river enters the city realm. Even though a natural pattern of nutrient concentrations may be present, the signal is swamped by anthropogenic sources of phosphorus and nitrogen species.

\subsection{Temporal variations and correlation with salinity}

At different times, dissolved silicate concentrations in the surface waters of the Danshuei Estuary ranged from 2 to $300 \mu \mathrm{M}$ (Fig. 6 and Supplementary Appendix), and often exhibited a behavior indicating linear dilution of freshwater by seawater during dry seasons (Fig. 6b,c, and others not shown), although the riverine concentrations can show considerable variability (i.e., $\sim 20 \%$, Supplementary Appendix). During wet seasons, as shown in Fig. $6 a$ and d, non-linear correlations with salinity were observed frequently, and especially displayed a significant net removal feature during August 2001 (Fig. 6a).

In the Danshuei Estuary, the dissolved phosphate concentration ranged from 0.1 to $35 \mu \mathrm{M}$ (Fig. 7). In general, distributions of dissolved phosphate were characterized by greater variability than those of silicate. At higher flow rates in wet seasons, phosphate concentrations were lower, and conversely, at lower river flow rates during the dry season, nutrient concentrations were higher (Supplementary Appendix). Dissolved phosphate usually showed non-conservative removal features with that of salinity (Fig. 7). a
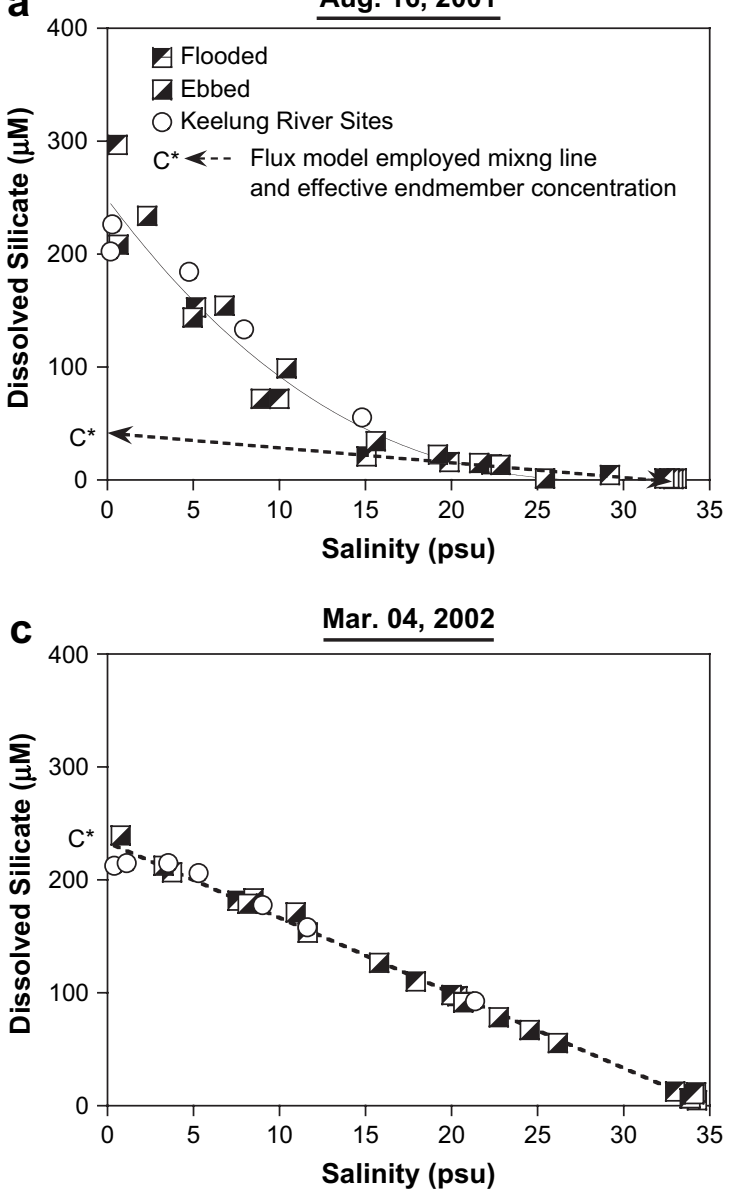

b
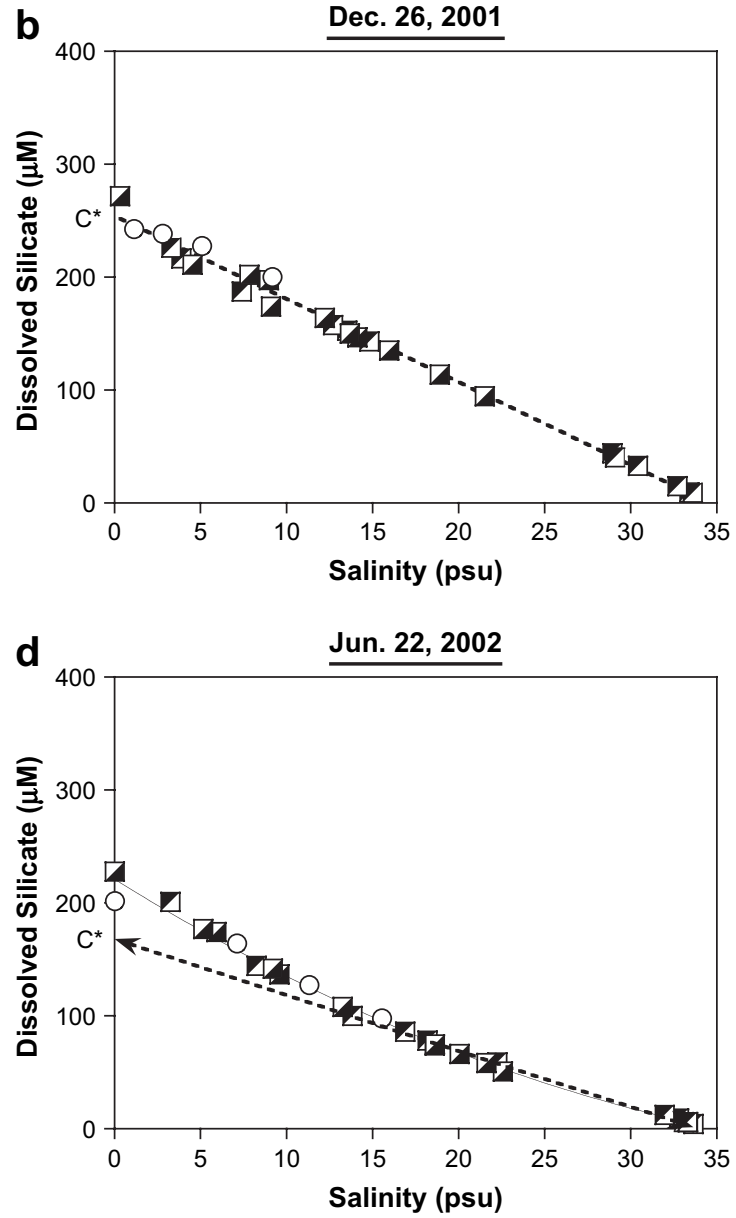

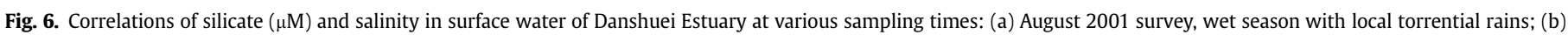

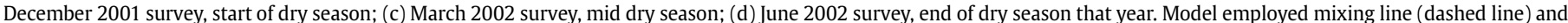
effective end-member $\left(C^{*}\right)$ are also indicated. ( $\mathbf{\square}$, waters collected during flood tide; $\mathbf{\square}$, waters collected during ebb tide; $\mathrm{O}$, waters collected at Keelung River). 

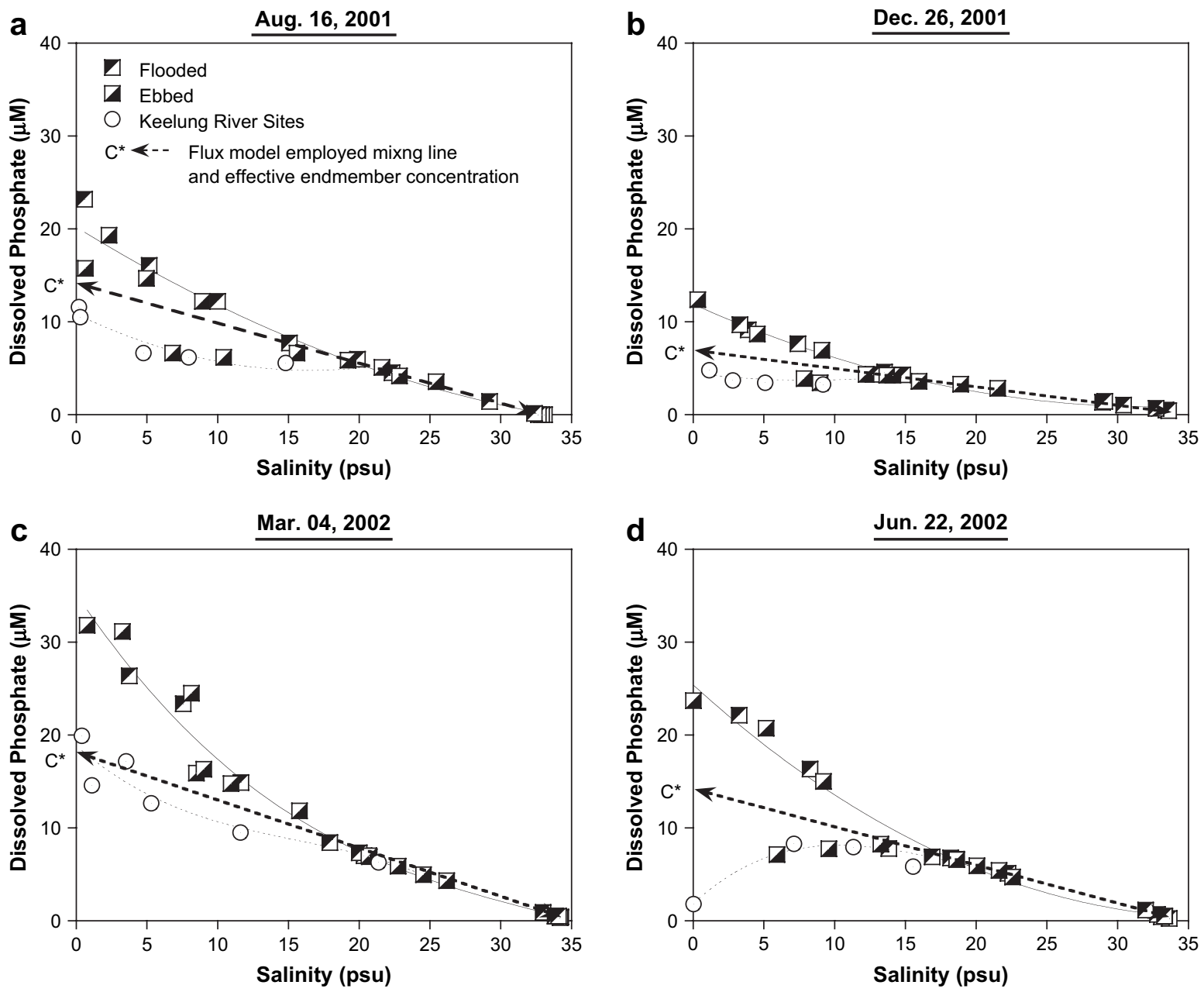

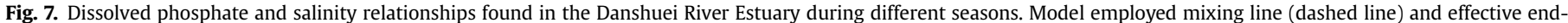
member $\left(C^{*}\right)$ are also indicated. ( $\mathbf{\square}$, waters collected during flood tide; $\mathbf{\square}$, waters collected during ebb tide; $\bigcirc$, waters collected at Keelung River).

However, distinctive variations in riverine concentrations of the Keelung River further complicate the steady-state interpretation. In most cases, the Keelung River bears a much lower (20-40\%) content of phosphates.

For dissolved inorganic nitrogen, except on July 18, 2001 and October 13,2001 , the predominant (>99\%) species in the waters of the whole estuary was ammonium, which behaved quasi-conservatively with concentrations ranging from 10 to $1000 \mu \mathrm{M}$ (Fig. 8). Nitrate and nitrite distribution over the salt gradient were nonconservative in all surveys, with convex curvature which mostly appeared with salinities of $>20 \%$. Nitrite and nitrate became more abundant during low river flow conditions, as distinctive differences in riverine concentrations of the Keelung River were also most pronounced. Conversely, under higher river flow conditions, substantial amounts were found in the inflows of the endmembers (Fig. 8).

These distribution and mixing behaviors of surface water were also evident for the whole water column throughout the estuary, where similar results were found for sample water collected at different depths on September 25, 2002 (Supplementary Appendix). To address the possible effluent inputs from the water treatment facilities, on one occasion (June 19, 2001), the dissolved inorganic nitrogen and phosphate concentrations were also measured in the effluents of the major water treatment plant in Taipei (Fig. 1), nitrite and nitrate concentration were both below $0.2 \mu \mathrm{M}$, ammonium was found to be $1718 \pm 60 \mu \mathrm{M}$ and phosphate to be $43 \pm 1 \mu \mathrm{M}$, respectively (Supplementary Appendix).

\section{Discussion}

\subsection{Seasonal variations and anthropogenic impacts}

Based on two dimensionless parameters (stratification and circulation), the Danshuei Estuary is often presented as a partially mixed salt structure, and is classified as type 2 according to the stratification circulation diagram of Hansen and Rattray (1966). The estuarine processes are influenced strongly by freshwater inputs and tides. In most cases, waters upstream from Guandoo were mostly anoxic. The hypoxic character of the Danshuei Estuary is determined primarily by the magnitude and duration of tidal inflows from coastal seawater. The anoxic water column oscillates up and down stream under changing tidal conditions, forming a highly active geochemical redox reactor, resulting in a transition zone from anoxia to sub-oxia in the water column changing every $6 \mathrm{~h}$. Such changes had major impacts on water quality in the study area which were also found in other regions (e.g., Glibert et al., 1995; Tallaksen et al., 1997; Carpenter et al., 1998; Howarth et al., 2002; Smith et al., 2003). Apart from the upper reaches of the river system, we observed exceptionally high nutrient concentrations in surface and also sub-pycnocline waters, as anoxia persisted in the water column, density stratification and tidal currents produced 
a

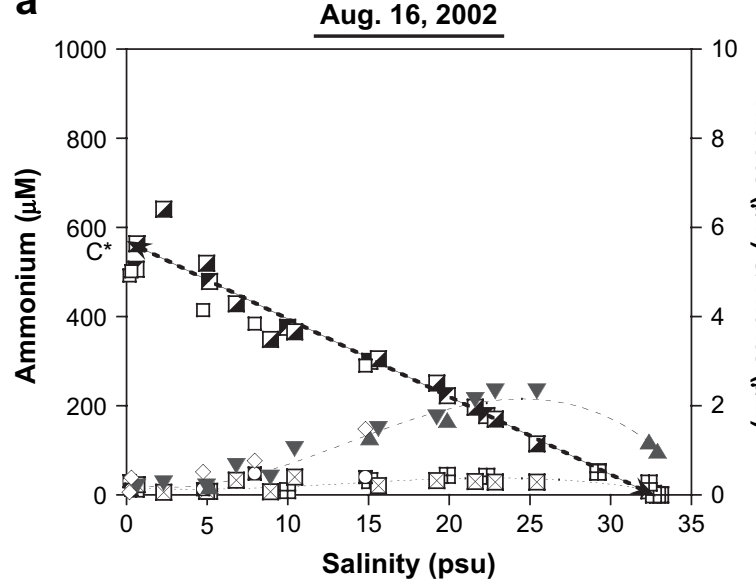

C

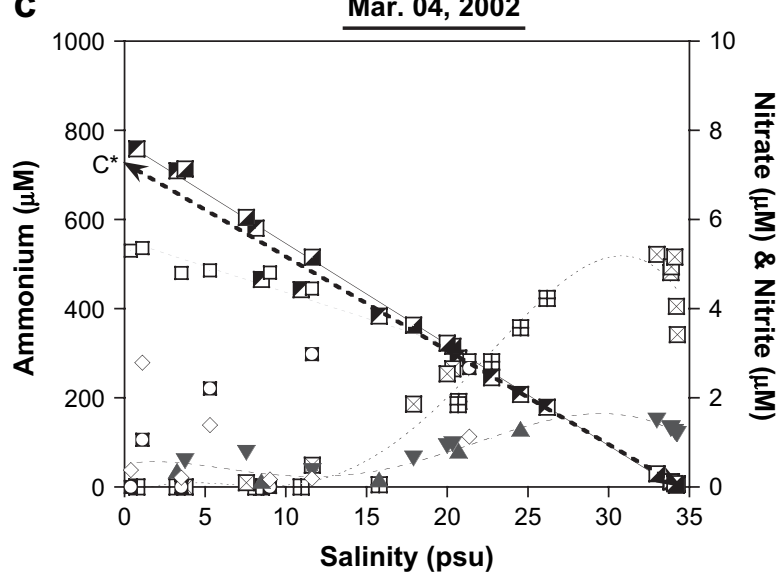

b
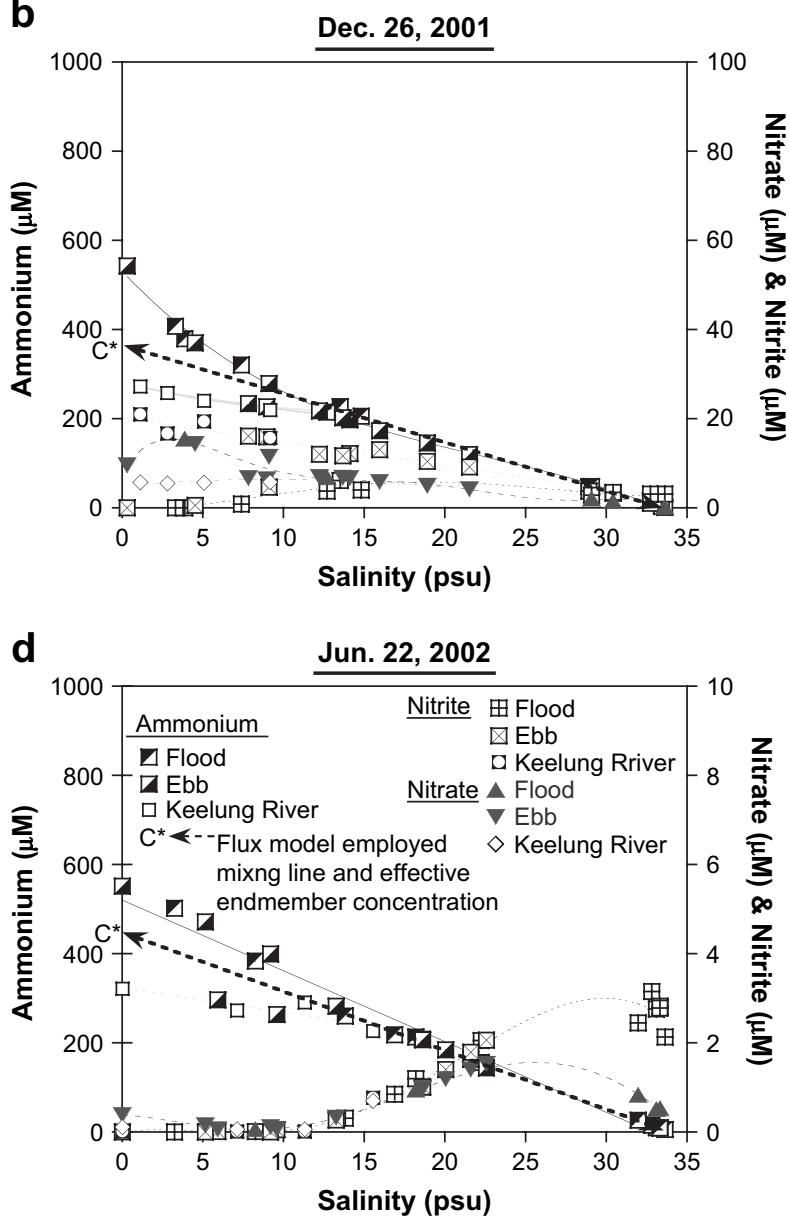

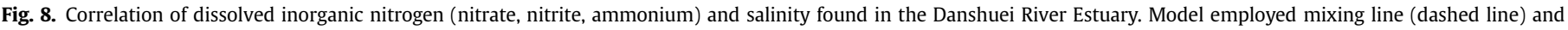
effective end-member $\left(C^{*}\right)$ are also indicated. ( $\mathbf{\square}$, waters collected during flood tide; $\mathbf{\square}$, waters collected during ebb tide; 0 , waters collected at Keelung River).

elaborate and complex patterns of nutrient distributions, exhibiting, at times, both conservative and non-conservative behavior (Fig. 6-8). The distribution of nutrients in sub-pycnocline waters was also comparable to that of surface waters (Supplementary Appendix), implying little net regeneration below the pycnocline.

Silicic acid does not have an anthropogenic source, and thus, can serve as an indicator of natural processes. Most of the silicic acid entering the estuary from the Danshuei River was transported to the sea. The silica-salinity relationship did not change as a function of tidal conditions. On one occasion (August 16, 2001), a significant net removal of silica by plankton production as indicated by significantly higher concentrations of chlorophyll- $a(5-100 \mu \mathrm{g} / \mathrm{l})$ at the time (Li et al., 2002; Supplementary Appendix). Overall, it is likely that little of the total silica flux is retained in the sediments of the estuary, a geochemical behavior which is different from other $\mathrm{N}$ and P-enriched estuaries (i.e., D'Elia et al., 1983; Froelich et al., 1984; Berner and Berner, 1996).

Early studies had indicated that only about $10 \%$ of the naturally weathered phosphorus carried by rivers is potentially available to marine biota, as in orthophosphate. Since the solubility product of apatite is only about $10^{-58}$ at a seawater $\mathrm{pH}$ of 8.0 , the phosphorus concentration in equilibrium with apatite would only be about $10^{-8} \mathrm{M}$ (Stumm and Morgan, 1996). In the Danshuei Estuary, $\mathrm{pH} 7-8$, dissolved phosphate concentration is in excess of that in equilibrium with respect to apatite; in fact, its concentration ranged from 0.1 to $35 \mu \mathrm{M}$ (Fig. 7), which places it at the upper end of concentrations in world rivers (Carpenter et al., 1998; Howarth et al., 2002; Smith et al., 2003). Concentrations of DIN in the Danshuei
River and its tributaries were much higher than the world average (Boyer et al., 2006), i.e. 400-1000 $\mu \mathrm{M}$ nitrogen, with mostly ammonium over the entire salt gradient in all surveys, with considerable influence on nitrate and nitrite distributions (Fig. 8). The outflow of effluents ( $\sim 80$ tons/day) into the upper Danshuei River had significantly elevated the concentration of dissolved ammonium from around $160 \mu \mathrm{M}$ to $499 \mu \mathrm{M}$, and the concentration of dissolved phosphate from $4.5 \mu \mathrm{M}$ to $16.3 \mu \mathrm{M}$ in the receiving river water. These findings were similar to the well-documented example of the Hudson River. In the 1980s, the Hudson River Estuary received a daily sewage input of $1.6 \times 10^{5} \mathrm{~kg}$ nitrogen into the estuary, which led to a total inorganic nitrogen concentration in the water of about $60 \mu \mathrm{M}$ (Malone, 1982, 1984), and resulted in major changes in the ecosystem.

\subsection{Nutrient fluxes and export loadings}

On average, most of the dissolved inorganic nitrogenous species carried in river waters were transported out to the coastal ocean, and $\sim 25 \%$ of dissolved phosphates were removed and sink in the estuary. As for silicate, large variations were found at different sampling dates; a large sink was observed during August 2001, possibly via biological uptake, since extremely high concentrations of chlorophyll- $a(4-100 \mu \mathrm{g} / \mathrm{l})$ in the water column with evidence of diatom blooms were found (Supplementary Appendix). Although the river flux varied greatly between the different survey times, the nutrient exporting fluxes were within the same order of magnitude for each of the dissolved nutrients. This indicates that the main 
Table 2

Comparison of average annual dissolved nutrient export loadings of Danshuei Estuary to that of several of the world's major rivers

\begin{tabular}{lllll}
\hline River system & $\begin{array}{l}\text { Drainage area } \\
\left(10^{6} \mathrm{~km}^{2}\right)\end{array}$ & $\begin{array}{l}\text { Water discharge } \\
\left(\mathrm{km}^{3} / \text { year }\right)\end{array}$ & $\begin{array}{l}\text { Nitrogen } \\
(\text { Gmol/year })\end{array}$ & $\begin{array}{l}\text { Phosphorus } \\
(\text { Gmol/year })\end{array}$ \\
\hline Danshuei & 0.0027 & 6.6 & $1.7-3.2$ & $0.05-0.1$ \\
Mississippi & $3.27^{\mathrm{e}}$ & $580^{\mathrm{e}}$ & 120 & 3.2 \\
Changjiang & $1.94^{\mathrm{e}}$ & $900^{\mathrm{e}}$ & $44.7^{\mathrm{c}}$ & $0.53^{\mathrm{c}}$ \\
Huanhe & $0.77^{\mathrm{e}}$ & $59^{\mathrm{e}}$ & $5.1^{\mathrm{c}}$ & $0.02^{\mathrm{c}}$ \\
Pearl & $0.45^{\mathrm{e}}$ & $315^{\mathrm{d}}$ & $28^{\mathrm{d}}$ & $0.3^{\mathrm{d}}$ \\
World rivers & & $35,000^{\mathrm{e}}$ & $1350^{\mathrm{a}}$ & $74^{\mathrm{b}}$ \\
\hline
\end{tabular}

${ }^{a}$ Data as in total dissolved inorganic nitrogen (DIN) from Smith et al. (2003).

b Data as in dissolved ortho-P from Smith et al. (2003).

c Data from Chang (1996).

d Data from Cai et al. (2004).

e Water discharge and drainage area from Milliman and Meade (1983) and Milliman and Syvitski (1992).

sources were input on a constant basis and not really affected by the natural weathering or erosion processes, leading to a conclusion of urban sewage runoffs. Compared to some major rivers in Asia (Changjian and Huanghe), North America (Mississippi), and the similar subtropical estuary in Asia (Pearl), the Danshuei River system, despite its much smaller drainage basins and reduced water discharge rates, introduces comparable amounts of DIN and DIP into the global ocean (Table 2). On average, applying the annual water discharge rate $\left(\sim 6600 \times 10^{6} \mathrm{~m}^{3} /\right.$ year $)$ to the average of effective river end-member concentration $\left(C^{*}\right)$, the annual loading rates of dissolved phosphate and dissolved inorganic nitrogen from the Danshuei River into the ocean are 0.1 and $3.2 \mathrm{Gmol} / \mathrm{year}$, respectively, representing $0.1 \%$ and $0.2 \%$ of the dissolved inorganic nitrogen and phosphate discharged by all the river systems in the world today (Smith et al., 2003). However, since the annual water discharge rate is heavily influenced by episodic events (i.e. typhoons), such conventional estimations of nutrient flux may be biased. Hence, if we apply only the average of nutrient fluxes computed from our survey results, the annual loading rate of dissolved phosphate and dissolved inorganic nitrogen would be reduced to 0.05 and $1.7 \mathrm{Gmol} /$ year, respectively (Table 2). As the outflow of effluents from the major water treatment plant in Taipei was found to introduce 50,166 mol/year of DIN and $1256 \mathrm{~mol} / \mathrm{year}$, respectively, this would indicate most of the nutrient pollution (>90\%) would come from non-point sources. The DIN:DIP loading ratio that we derive $(32: 1)$ is much higher that the ratio $(18: 1)$ reported by Meybeck (1982) and Smith et al. (2003). These results were consistent with the hypothesis and observations that DIN exports constitute the majority of dissolved $\mathrm{N}$ export from regions with heavy human influence (Vitousek et al., 1997; Howarth et al., 2002; Fulweiler and Nixon, 2005).

The average annual loading rates of dissolved phosphate and dissolved inorganic nitrogen from the Danshuei River represent $0.05-0.11 \%$ and $0.1-0.2 \%$ of the world's total river discharge of dissolved inorganic nitrogen and phosphate, and yet are derived from only $0.024 \%$ of the Earth's sub-aerial surface. These excessive loadings would have profound impacts on the nutrient loading on the shelf and consequent regional problems with potentially large economic impacts.

\section{Acknowledgements}

We would like to thank Miss Wen-Hui Li, Lee-Ying Wu, Jia-Ying Chuang, I-Ting Jiang, Dr Shi-Wei Chung, and research assistants of the Chemistry Laboratory of National Center for Ocean Research at National Taiwan University for help with the sampling and ancillary analysis. The assistance of the crew and technicians on board the research vessel, Ocean Research-II, during the sampling expeditions is greatly appreciated. We thank Dr Ivan Valiela and two anonymous reviewers for their insightful comments and suggestions that helped improve the manuscript. This research was, in part, supported by the National Science Council grant NSC-89-2611-M-002-054, NSC-90-2611-M-002-024, NSC-912611-M-002-07 and National Center for Ocean Research. This is NCOR publication number 120 .

\section{Appendix A. Supplementary material}

Supplementary material associated with this article can be found, at doi:10.1016/j.ecss.2008.02.011.

\section{References}

Berner, E., Berner, R., 1996. Global Environment. Water, Air and Geochemical Cycles. Prentice Hall, Uppersaddle River, NJ, USA.

Boyle, E., Collier, R., Dengler, A., Edmond, J., Ng, A., Stallard, R., 1974. On the chemical mass-balance in estuaries. Geochimica et Cosmochimica Acta 38, 1719-1728.

Boyer, E.W., Howarth, R.W., Galloway, J.N., Dentener, F.J., Green, P.A., Vörösmarty, C.J., 2006. Riverine nitrogen export from the continents to the coasts. Global Biogeochemical Cycles 20, GB1S91.

Cai, W., Dai, M., Wang, Y., Zhai, W., Huang, T., Chen, S., Zhang, F., Chen, Z., Wang, Z., 2004. The biogeochemistry of inorganic carbon and nutrients in the Pearl River estuary and the adjacent Northern South China Sea. Continental Shelf Research 24, 1301-1319.

Carpenter, S., Caraco, N., Correll, D., Howarth, R., Sharpley, A., Smith, V., 1998. Nonpoint pollution of surface waters with phosphorus and nitrogen. Ecological Applications 8, 559-568.

Chung, S.-W., Wen, L.-S., Chuang, C.-Y., Sue, T.-T., 2001. Salinity/ionic effect on nutrients analysis in natural waters. Chemistry (The Chinese Chemical Society) 59, 311-316.

Dadson, S., Horlus, N., Chen, H., Dada, W., Hsieh, M., Willett, S., Hu, J., Horng, M., Chen, M., Stark, C., Lague, D., Lin, J., 2003. Links between erosion, runoff variability and seismicity in the Taiwan orogen. Nature 426, 648-651.

D’Elia, C., Nelson, D., Boynton, W., 1983. Chesapeake Bay nutrient and plankton dynamics: III. The annual cycle of dissolved silicon. Geochimica et Cosmochimica Acta 47, 1945-1955.

Dumont, E., Harrison, J., Kroeze, C., Bakker, E., Seitzinger, S., 2005. Global distribution and sources of DIN export to the coastal zone: results from a spatially explicit, global model. Global Biogeochemical Cycles 19, GB4S02.

EPA, 2006. Environmental White Paper. Environmental Protection Administration, Taiwan, Republic of China (in Chinese).

Froelich, P., Kaul, L., Byrd, J., Andreae, M., Roe, K., 1984. Arsenic, barium, germanium, tin dimethylsulfide and nutrient biogeochemistry in Charlotte Harbor Florida, a phosphorus-enriched estuary. Estuarine, Coastal and Shelf Science 27, 61-93.

Fulweiler, R., Nixon, S., 2005. Export of nitrogen, phosphorus, and suspended solids from a southern New England watershed to Little Narragansett Bay. Biogeochemistry 76, 567-593.

Galloway, J., Dentener, F., Capone, D., Boyer, E., Howarth, R., Seitzinger, S., Asner, G., Green, C., Holland, E., Karl, D., Michaels, A., Porter, J., Townsend, A., Vörösmarty, C., 2004. Nitrogen cycles: past, present and future. Biogeochemistry 70, 153-226.

Ghassemzadeh, F., Sherwood, J., Geddes, M., Williams, W., 1997. The analysis of nitrate in highly saline waters. International Journal of Salt Lake Research 6, 269-278.

Glibert, P.M., Conley, D.J., Fisher, T.R., Harding, L.W., Malone, T.C., 1995. Dynamics of the 1990 winter spring bloom in Chesapeake Bay. Marine Ecology ProgressSeries 122, 27-43.

Grasshoff, K., 1999. Methods of Seawater Analyses, third ed. Weinheim.

Green, P., Vörösmarty, C., Meybeck, M., Galloway, J., Peterson, B., Boyer, E., 2004 Pre-industrial and contemporary fluxes of nitrogen through rivers: a global assessment based on typology. Biogeochemistry 68, 71-105.

Griffiths, G.A., Glasby, G.P., 1985. Input of river-derived sediment to the New Zealand continental shelf. Estuarine, Coastal and Shelf Science 21, 773-787.

Howarth, R., Walker, D., Sharpley, A., 2002. Sources of nitrogen pollution to coastal waters of the United States. Estuaries 25, 656-676.

Lao, R.C., Young, Y.S., 1995. Water pollution control measures in Taiwan. Water Quality Research Journal of Canada 30, 143-150.

Li, Y.-H., 1976. Denudation of Taiwan island since the Pliocene epoch. Geology 4, 105-107.

Li, H., Wen, L., Ong, H., Song, S., Chung, E., Liu, K., 2002. Photopigments and primary production in Danshuei estuary, Annual Ocean Science Conference. National Science Council, Taitung, Taiwan. December 23-25.

Liss, P., 1976. Conservative and non-conservative behavior of dissolved constituents during estuarine mixing. In: Burton, J.D., Liss, P.S. (Eds.), Estuarine Chemistry. John Wiley \& Sons Ltd., Chichester, pp. 93-127.

Liu, W.-C., Hsu, M.-H., Kuo, A., 2002. Modeling of hydrodynamics and cohesive sediment transport in Tanshuei River estuarine system. Taiwan. Marine Pollution Bulletin 44, 1076-1088. 
704

L.-S. Wen et al. / Estuarine, Coastal and Shelf Science 78 (2008) 694-704

Malone, T., 1982. Factors influencing the fate of sewage-derived nutrients in the lower Hudson estuary and the New York Bight. In: Mayer, G.F. (Ed.), Ecological Stress in the New York Bight: Science and Management. Estuarine Research Foundation, Columbia, SC, pp. 301-320.

Malone, T., 1984. Anthropogenic loading and assimilation capacity of the Hudson River estuarine system, USA. In: Kennedy, V.S. (Ed.), The Estuary as a Filter. Academia Press, Orlando, FL, pp. 921-930.

Mantoura, R., Llewellyn, C.A., 1983. The rapid determination of algal chlorophyll and carotenoid pigments and their breakdown products in natural waters by reverse-phase high-performance liquid chromatography. Analytica Chimica Acts 151, 297-314.

Meybeck, M., 1982. Carbon, nitrogen and phosphorus transport by world rivers. American Journal of Science 282, 401-450.

Milliman, J., Farnsworth, K., Albertin, C., 1999. Flux and fate of fluvial sediments leaving large islands in the East Indies. Journal of Sea Research 41, 97-107.

Milliman, J.D., Meade, R.H., 1983. World-wide delivery of river sediment to the oceans. Journal of Geology 91, 1-21.

Milliman, J.D., Syvitski, P.M., 1992. Geomorphic/tectonic control of sediment transport to the ocean: the importance of small mountainous rivers. Journal of Geology $100,525-544$.

Officer, C., Lynch, D., 1981. Dynamics of mixing in estuaries. Estuarine, Coastal and Shelf Science 12, 525-533.

Pail, S.-C., Gong, G., Lu, K.-K., 1993. Determination of dissolved oxygen in seawater by direct spectrophotometry of total iodine. Marine Chemistry 41, 343-351.

Pal, S.-C., Tsau, Y.-J., Yang, T.-I., 2001. pH and buffering capacity problems involved in the determination of ammonia in saline water using the indophenol blue spectrophotometric method. Analytica Chimica Acta 434, 209-216.
Rabalais, N.N., 2002. Nitrogen in aquatic ecosystems. Ambio 31, 102-112.

Smith, S.V., Swaney, D.P., Talaue-McManus, L., Bartley, J.D., Sandhei, P.T., McLaughlin, C.J., Dupra, V.C., Crossland, C.J., Buddemeier, R.W., Maxwell, B.A., Wulff, F., 2003. Humans, hydrology, and the distribution of inorganic nutrient loading to the ocean. Bioscience 53, 235-245.

Song, G.-S., Wen, L.-S., Lu, K.-K., Lu, P.-K., 2002. Underwater topography in the downstream portion of Tanshui River. Acta Ocean Taiwanica 40, 25-30.

Stumm, W., Morgan, J.J., 1996. Aquatic Chemistry, Chemical Equilibria and Rates in Natural Waters, third ed. John Wiley \& Sons, Inc., New York.

Tallaksen, L., Madseb, H., Clausen, B., 1997. On the definition and modeling of streamflow drought duration and deficit volume. Hydrological Science Journal 42, 15-33.

Vitousek, P.M., Abr, J., Bayley, S.E., Howarth, R.W., Likens, G.E., Matson, P.A., Schindler, D.W., Schlesinger, W.H., Tilman, G.D., 1997. Human alteration of the global nitrogen cycle: causes and consequences. Ecological Applications 7, 737-750.

Wen, L.-S., Santschi, P., Gill, G., Paternostro, C., 1999. Estuarine trace metal distributons in Galveston Bay: importance of colloidal forms in dissolved phase speciaction. Marine Chemistry 63, 185-212.

Wen, L.-S., Santschi, P., Gill, G., Tang, D., 2002. Silver concentrations in Colorado, USA Watersheds using improved methodology. Environmental Toxicology and Chemistry 21, 2040-2051.

WRA, 2001. Hydrological Year Book of Taiwan. Ministry of Economic Affairs, Water Resources Agency, Taipei, Taiwan, ROC.

WRA, 2002. Hydrological Year Book of Taiwan. Ministry of Economic Affairs, Water Resources Agency, Taipei, Taiwan, ROC. 